\title{
The Opportunities and Constraints of Providing Health and Social Security for Domestic Workers in Yogyakarta
}

\author{
$1^{\text {st }}$ Muryanti* \\ Sociology Department \\ UIN Sunan Kalijaga \\ Yogyakarta, Indonesia \\ newsyant@yahoo.com
}

\author{
$2^{\text {nd }}$ Ekawati Sri Wahyuni \\ Rural Sociology Department \\ $I P B$ University \\ Bogor, Indonesia \\ ekawatiwahyuni@gmail.com
}

\begin{abstract}
Domestic Helper or Domestic Workers (PRT) or Household Assistance (ART) are categorized as informal workers or non-wage workers who have several models of work, namely: fulltime and part time. Todays, domestic workers who are previously informal workers are changed to become formal workers, with the rules of work contracts, working hours, days off, division of labor and social security. This research is a qualitative research with the process of searching data through interviews and observations. Interviews were conducted with 5 informants participating in social security and 5 informants not participating in social security. Karl Marx's theory of Surplus Value is used for analyzing the data. The results showed that domestic workers have the desire to become social security participants because their work is vulnerable to accidents and the risk of illness that requires high costs. In fact, their participation in social security is low because they have low income and just enough to fulfill of the family needs, so they cannot pay social security fee every month. Thus BPJS (The Indonesian National Health Insurance System) must be continuously socialized to domestic workers and they should reduce the monthly fee. To improve the participation in social security is through a community approach. PRT can registration and payment process through domestic workers organizations. With the main target, the employer is involved in payments every month. The community approach has proven to be effective in increasing the number of participation which should be accompanied by the strengthening of organizations and activists of domestic workers organizations. The future jobs that need to be done are to invite PRT who are not affiliated with domestic workers organizations to become BPJS's member.
\end{abstract}

Keywords-domestic worker, social security, human rights, organization

\section{INTRODUCTION}

Domestic workers (PRT) with various names (rewang, servants, housemaid and housekeeper) have an important role in the family in Indonesia. Domestic workers are defined as people who provide services for various types of domestic work [1]. Their experience to accompany the family lasted a long time since the Dutch Colonialism, which involved transcendental, psychological and economic relations [2].

Today, the change of a society that has shifted from a postmodern to a digital society has caused relations between employers (the term for users of domestic work services) to change in work relationships to. In the past, employers generally assumed that domestic workers were informal workers who did all the domestic work. In this perspective, domestic workers are informal worker. This informality can be seen from the unclear wages and working hours, heavy workloads (for all types of household work), low wages, uncertain holidays and family relations. For example, this pattern includes full time domestic workers who live in the employer's house, part time domestic workers with all domestic work or ngenger domestic workers (a term for them who live in the homes of their wealthier and more respectable relatives, they don't get paid and they do all household work in employer's house) [3].

The second category is those domestic workers who are formalized because a part of their job is suitable with formal job criteria. The formality is seen in the division of labor of household work (they are all not household workers); there are employment contracts with fixed salary (according to the minimum wage), the days off, and the relationship which is more formal. The employer usually gets information about domestic workers from outsourcing company or hospitals and formal relationships between employers and domestic workers. For instance: baby sitter, pramurukti (elderly nurses and sick people), domestic workers with specific jobs and cleaning services [4].

The category of household work is such as washing, cooking, ironing, drying clothes, cleaning the house and all contents (household furniture), cleaning the garden, guarding the house, caring for children, dropping to school children, shopping and all household work. Those jobs are prone to have accidents, for example: slipping due to slippery floors both in the house or bathroom, electric shock due to chipped cables, slippery stairs when drying clothes, gas leaks, prone to fall from apartments' $16^{\text {th }}$ floors, the use of chemicals in washing clothes or skin irritation because of house cleaners, sexual harassment, and leaky roofs that can cause slipping [5]. Therefore, the vulnerability at work requires social security and health protection.

This paper wants to describe the importance of social security for domestic workers both formal and informal, and the obstacles faced by employers in providing social security and the challenges of providing social security from employment to domestic workers. It employs Karl Marx's 
theory on value as theoretical framework which related to strengthening the value of domestic workers for employers, with social security provided for domestic workers.

\section{RESEARCH AND METHOD}

This research uses a critical paradigm that carries out criticism and social transformation [6]. This paper aims to find evidence as a mean to provide justice from employers to domestic workers, regarding the provision of employment social security. Data collection methods are carried out through observation, in-depth interviews and secondary data analysis. Observations are done by observing how domestic workers who complete domestic work are vulnerable to work accidents. In-depth interviews were conducted with 5 domestic workers with BPJS employment participants and 5 informants without BPJS employment in Yogyakarta. The results of the study will be combined primary data and secondary data related to several events that cause workplace accidents on domestic workers.

\section{IRESULT AND DISCUSSION}

\section{A. Health and Employment Social Security for Workers in the Informal Sector}

Informal sector or self-employed workers are those who work outside the employment relationship [7]. Informal workers are categorized as low workers. This job arises because these workers do not get access to work in the modern economy (Portes) so their income is low [8]. Keith Hart and Effendi stated that the informal sector provides opportunities for urban communities to find work, as an alternative employment strategy to earn additional income or reduce unemployment both in the village and in the city [9]. According to the ILO, the informal concept refers to the work sector which is carried out independently and with a variety of types of work. These job characteristics are (1) low skills, capital and organization; (2) family based; (3) small business scale; (4) low-tech production processes and (5) lack of rules. In Indonesian context, informal workers are scattered in various types of work including: peddlers, grocery traders, street vendors, tire fillers, drink sellers, scavengers, motorcycle taxi drivers, parking assistants, food vendors, hawkers, predictable drivers, salon, barbershop, tailor, contract owner, janitor, photocopy service, retail gasoline seller, service provider, clothes seller, farmer, fisherman and housemaid [10].

The work situation in the informal sector needs protection, so the continuity of work can be sustainable. The lack of social security in this job makes them need to be given protection, maintenance and improvement of welfare so it will increase national productivity. The social security program for workers is useful for minimizing risks and providing composure for workers. Workers' social security supports independence and human dignity in the face of socio-economic vulnerability.

The workforce social security program is a basic protection for workers and their families by providing compensation when work accidents occur, with facilities such as life insurance and pension insurance. Thus, this program provides legal certainty for the ongoing receipt of family income in part or all when they lost income.
According to the head of the office of BPJS, the importance of the participation of informal sector workers in the social security program for workers is (1) providing social economic protection; (2) providing legal protection for socioeconomic risks and (3) guaranteeing the family. On the other hand, there are several obstacles that prevent them from participating in social security programs. The situation of informal worker causes the role of the government in providing protection and mechanisms for regulating health insurance and employment for them.

The Government of Indonesia provides health and employment insurance through BPJS for informal workers. Some facilities provided to members of BPJS employment: (1) Work Accident Insurance (JKK), which has benefits in the form of cash and or health services provided when a participant experiences an occupational accident starting to leave work until arriving back at home or illness caused by work environment. Work Accident Insurance (JKK) which includes costs for embarking, medical and treatment costs, while unable to work (STMB = Sementara Tidak mampu Bekerja) will get wages, replacement denture, disability compensation, compensation for death for work accident insurance, rehabilitation costs and scholarship assistance [11]; (2) Death Assurance (JKM) given to the heirs of labor participants of BPJS employment who die due to work accidents. JKM is needed to help ease the burden on the family in the form of funeral costs and compensation; (3) Old Age Security (JHT) is a cash benefit that is paid at the same time when a participant stops working, dies, has total permanent disability or leaves Indonesia forever; (4) Old Age Security (JHT) provided for the accumulated value of all JHT contributions that have been paid plus the results of its development and (5) Death Assurance (JKM) given to the worker's family includes: death benefit, periodic compensation, funeral expenses and educational scholarships one child is given to the participant's child who dies due to a work accident and has a contribution of at least 5 years.

In this time, the performance of BPJS employment is good. The success and obstacle of it for the Informal Sector have been influenced by several factors. The obstacles of implementation BPS employment program are: (1) facility factors (service facilities): the use of drive thru facilities that have not been optimal (only in the office environment and certain periods); (2) human resources factors: lack of personnel in the service sector and non-wage recipient marketing sector; (3) technological factors: the weakness of the server in the application, so that when the application is used it often experiences down or errors; (4) political factors: the government is not yet present massively implementing the policies that have been set related to BPJS Employment, especially PP No. 86 of 2013 and (5) social factors: the perception of informal workers who do not consider their participation in labor social security as important [12].

Social factors are main factor why they don't take part in social security participation. There are several reasons for the low participation of the social security program, namely manageable causes and causes that cannot be handled (unmanageable). Causes that can be addressed include the lack of public knowledge, lack of socialization, lack of health promotion media and family heads less aware of the importance of the social security program. The causes that cannot be addressed are low education [13]. 
The participation of workers in the informal sector in the BPJS program is very low. Approximately only $0.5 \%$ of the informal sector workers in Indonesia have commercial insurance. The numbers of informal workers are 73.98 million of 87.08 million people in total worker population [14]. These numbers show that informal sector workers are low participant in health [15] and employment social security program. In fact, they have a high interest in participating in the social security program due to awareness of risks to health and work accidents. However, there are several rational reasons why they did not participate in the program. The rationality appears to be influenced by factors of type of work, level of education and level of knowledge [16].

Some doubts about participation in social security arise among these workers because of the high fee of commercial insurance [17] and they rarely get sick and have work accidents, low incomes [18] and uncertain income which averages range between 1,000,000-1,500,000 rupiah per month [19]. They become family backbone with 2-3 family burden. The health services using insurance are still not good so that the impact on the quality of health services is low and there is no family support [20]. Without family support, they can be sure to pay monthly contributions because of their existence as the backbone of family. In addition, they also lack information and socialization, so the use of information media and the right amount of contributions are expected to increase the number of BPJS's participants. In addition, they felt they did not need and understand the procedures and benefits of social security and they listened many complaints from people about

\section{B. Health and Employment Social Security for Domestic Workers}

Domestic workers can be categorized into two: formal and informal domestic workers. Although there are formal and informal domestic workers, in the context of work relations the two categories don't have much difference, especially in the provision of social security health and employment. Outsourcing company or employers doesn't care of the provision of social security to them. They only provide wages to domestic workers, that it don't include social security items. If they get a work accident, the outsourcing company and employer provide compensation voluntarily, which is separate from the wages given each month. Domestic workers who wish to become social security participants must be independent (self-pay) who are not related to employers and outsourcing company.

The existence of Minister of Manpower's regulation No. 2 of 2015 concerning Protection of Domestic Workers is one way to open a social security for domestic workers. In Chapter III article 11 (g) it is written, the obligation employers to domestic workers services is to be included in the social security program [21]. The regulation becomes the legal basis that the outsourcing company or employer is required to provide social security to domestic workers. But in practice, many employers and foundations don't provide social security.

That ministerial regulation encouraged the government to make easier for BPJS membership regulation for informal workers. The government issued a BPJS employment policy for Non-Recipient Workers. The government has promoted this program to domestic workers through the Serikat PRT and Organisasi Pekerja Rumah Tangga (Operata) since 2017 by providing facilities, including: cheap monthly fee, 16,000 rupiahs and in 2019 (currently) 36,800 rupiahs of fee, free of charge 3 months fee payment, ease of registering through the organization and ease in claiming when an accident occurs at all hospitals (without use the referral hospital).

The organizational approach is one of the ways done by the BPJS to attract participants among domestic workers. This matter is related the nature of the organization that has a hierarchical approach, trust and kinship so that it is expected that there is compliance by members in this social security program. The main objective is to build collectivity in social security participation, facilitate socialization about the program through monthly activities organized by the organization, strengthen collective identity that encourages them to participate in social security and easily control monthly contributions that they can be paid in time.

In practice, BPJS employment cooperates with the PRT National Advocacy Network (JALA PRT) as one of the organizations fighting for the rights of domestic workers for the registration and payment process. By collaborating with JALA PRT, participation of domestic workers can be comprehensive from several regions in Indonesia (JakartaBogor-Tangerang-Bekasi, DIY, Semarang and Medan) as well as being a pilot project for outsourcing company or domestic workers organizations to provide social security. The number of participants who registered through JALA PRT was 598 domestic workers and 183 people from the general category (not domestic workers). So until May 2020, the total number of participants was 781. The numbers of participants were 16 people from Yogyakarta. They divided into two categories: 4 people being borne by the employer and 12 people paying independently. The criteria of domestic workers that participate in this program: They don't have large family responsibilities (for example school children fee or carrying sick husband/ children/parents). In early 2020, BPJS participants through JALA PRT were able to get benefits due to work accidents and deaths.

This social security program provides benefits for both, employers and domestic workers. Benefits for Employers, if at any time domestic workers experience workplace accidents, they do not need to bear large costs, just submit a claim to BPJS Employment, benefits for participants will definitely be given. This means with low fee, employers can get large services from domestic workers. As Marx's explanation of surplus value, by paying a fee, the surplus value obtained from domestic workers does not decrease. The benefit for domestic workers, they will get benefits in accordance with the benefits of the program: work accidents, old age and death. Participants can also take the money paid if membership has lasted 5 years, if there is no work accident and does not wait for old age. Similarly, participants who pay a fee such as savings can be taken at a specified time.

The benefits gained for employer and domestic worker do not encourage them to become participants or encourage employers to provide social security to domestic workers. There are several factors that cause domestic workers do not participate due to the minimal income 
(ranging from 500,000-1,000,000 rupiahs) which must be divided to pay various household needs so it make them difficult to pay fees every month, they already have recipient of contribution subsidy (Penerima Bantuan Iuran=PBI) and the Family Hope Program (Program Keluarga Harapan = PKH) from the government; they lack of information about the difference between health and employment social security and the dependence of domestic workers on the organization in the payment process that it make the activist organization as responsible person of this program, not the members of organization.

\section{The Challenges Social Security Program for Domestic Workers}

The challenge in the domestic workers' social security program is related to their ability to pay fee every month. Is the payment can be current payment or arrears payment? This fact is the duty of the government through BPJS to design this program more precisely. In practice, domestic workers have low wages. It still a major factor are influencing them to become participants. BPJS, Local Government and Hospitals need to periodically evaluate the paid fee by them every month.

Another major factor is related to the socialization of the program. It needs to continuously spread knowledge and awareness for them. The process of socialization carried out through this organization should be done in an innovative manner, so they will be interested in this program. The government should establish a cooperation with the private sector as an effort to expand BPJS employment membership [22], so that participants from the domestic workers group can expand to the members of the domestic workers union. In fact, many domestic workers are not members of the organization.

The effort of increasing membership has been done by (1) providing continuous socialization in a variety of innovative ways, both through organizations, door to door in urban and village by BPJS, village officials and domestic workers organizations; (2), increasing the availability of socialization media that are easily accessible by domestic workers and employer so they can easily understand the program; (3) proposing BPJS to campaign the importance of social security program to the community; and (4) supporting to personal in charge of domestic worker organizational who make success program.

\section{CONCLUSION}

Domestic workers need to have such health or employment insurance. In fact, they are vulnerable to work accidents while on their way to work, during work and on back from their way to work. If they are covered in social security program, it easier for domestic workers and employers because they are dealt with quickly in emergency situations, especially work accidents. Another advantage, the fee paid every month (at this moment) is very low, 36,800 rupiah in 2020 which is affordable in accordance with their income.

The employment social security program for non-wage workers is a program that was released in November 2019, with socialization conducted since 2017. The number of participants has approximately 700 people spread across
Jakarta-Bogor-Tangerang-Bekasi, DI. Yogyakarta, Semarang and Medan. Every year, we can be sure that the member will increase because all members of JALA PRT have been well socialized. Of course, this is done through socialization activities by domestic workers organizations continuously.

The domestic workers organization is institution in charge of social security participation for domestic workers as non-wage workers. Without the activeness of the organization, the number of domestic worker participants cannot increase. During this time, the process of approaches have been conducted by the community through various ways such as meetings, informal discussions, discussions with experts, coming to the workplace or using social media to campaign information program. The socialization and discussion can open their knowledge so they are interest to become participants. In once meeting only 1 or 2 people attended, sometimes no one is interested

By doing so, the organizations have role to increase the number of social security participants. So the strengthening of organizational needs to be improved. Today, the domestic worker organization has more than 10 activists in socializing the program. That number is minimal. Organizational strengthening can be done by providing support to activists directly or through organizations. Besides that, the socialization process should be done in outside organization, because the number of domestic workers who are not joined in the organization is greater than member of organization.

\section{ACKNOWLEDGMENT}

Thank you for my promotor in Bogor Agricultural University (IPB University), Dr. Ir. Ekawati Sri Wahyuni, MS and Domestic Workers in Yogyakarta and all committee members of the second Annual International Conference on Social Sciences and Humanities (AICoSH) for their insights in reviewing this article.

\section{REFERENCES}

[1] ILO, Kesetaraan dalam Pekerjaan Konsep dan Prinsip Utama, Jakarta: ILO Office, 2013.

[2] B. Purwanto, Jejak Seribu Tangan, Yogyakarta: Rumpun Tjoet Njak Dien, 2000.

[3] Muryanti, Perempuan Pedesaan: Kajian Sosiologis Pekerja Rumah Tangga/PRT, Yogyakarta: Bimasakti Publising, 2012.

[4] Muryanti, Relasi Kuasa Hubungan Kerja Domestik, Yogyakarta: Suluh Media, 2018

[5] Local Initiative for OSh, Pekerja Rumah Tangga(PRT) : Mengenal Bahaya dibalik Pintu, www.lionindonesia.org/blog, access at Maret 2020

[6] Guba, Lincoln, Norman K.D, "The Sage Handbook of Qualitative Research 1", Yogyakarta: Pustaka Pelajar, 2010, pp.209

[7] S.Anik and S.U Adillah, "Kebijakan Jaminan Sosial Tenaga Kerja Sektor Informal Berbasis Keadilan Sosial untuk Meningkatkan Kesejahteraan", Yustisia Vol.4, No.3, September-Desember 2015, pp. 558-580.

[8] T.N.Effendi, Urbanisasi, Pengangguran dan Sektor Informal di Kota, Jakarta: Yayasan Obor Indonesia, 1985.

[9] K.Hart, Informal Income Opportunities and Urban Employment in Ghana, in Press, 1996

[10] F.Andria and N.Kusnadi, "Model Alternatif Pembiayaan Jaminan Kesehatan bagi Pekerja Informal di Bogor", Pakuan Law Review, Vol. 4, No.2, Juli-Desember 2018, pp.175-185.

[11] BPJS Ketenagakerjaan, Program Jaminan Sosial Ketenagakerjaan bagi Pekerja Bukan Penerima Upah, www.bpjsketenagakerjaan.go.id, access at Februari 2020. 
[12] A.E.Zulfa and I.H.Dwimawan, "Analisis Kinerja BPJS Ketenagakerjaan Kantor Cabang Semarang Pemuda untuk Meningkatkan Perluasan Kepesertaan Sektor Informal", Journal of Public Policy and Management Review, Vol.7, No. 2, 2018.

[13] W.Kurniawati and R.D Rachmayanti, "Identifikasi Penyebab Rendahnya Kepesertaan JKN pada Pekerja Sektor Informal di Kawasan Pedesaan", Jurnal Administrasi Kesehatan Indonesia, Vol.6, No.1, Januari-Juni 2016, pp. 33-39

[14] Ipotnews, Pekerja Informal Dominasi Jumlah Total Pekerja pada Februari lalu (BPS), www.indopremier.com/ipotnews, access at Maret 2020

[15] A.D.Intiasari, L.Trisnantoro and Y.Hendrartini, "Potret Masyarakat Sektor Informal di Indonesia: Mengenal Determinan Probabilitas Keikutsertaan Jaminan Kesehatan sebagai Upaya Perluasan Kepesertaan pada Skema Non PBI Mandiri", Jurnal Kebijakan Kesehatan Indonesia, Vol.4, No.4, Desember 2015, pp. 126-132

[16] D.Lutfina, C.Suryawati, E.Y.Fatmasari, "Gambaran Sektor Informal Nelayan Kelurahan Cilincing Jakarta Utara sebagai Calon Peserta BPJS Kesehatan”, Jurnal Kesehatan Masyarakat, Vol.4, No.1, Januari 2016, pp.34-43

[17] B.E.Siswoyo, Y.S.Prabandari, Y.Hendrartini, "Kesadaran Pekerja Sektor Informal terhadap Program Jaminan Kesehatan Nasional di Provinsi Daerah Istimewa Yogyakarta",Vol.4, No.4, Desember 2015, pp. $118-125$

[18] M.Y.Abadi, D.S.Marzuki, M.A.Arifin, Darmawansah, "Analisis Kepesertaan Mandiri BPJS Kesehatan di Sektor Informal (Studi di Kota Makassar)", Jurnal Manajemen Kesehatan Yayasan RS. Dr. Soetomo, Vol. 5 No. 2, Oktober 2019, 114-124

[19] Nurbaeti, A.Surahman, "Kemampuan Membayar Iuran BPJS bagi Masyarakat Pekerja Sektor Informal (Studi pada Tukang Ojek Dan Becak/ Bentor)", Promotif: Jurnal Kesehatan Masyarakat, Vol.8, No.2, Desember 2018, pp.165-172

[20] V.F. Pangestika, S.P.Jati, A.Sriatmi, "Faktor - Faktor yang Berhubungan dengan Kepesertaan Sektor Informal dalam BPJS Kesehatan Mandiri di Kelurahan Poncol, Kecamatan Pekalongan Timur, Kota Pekalongan”, Jurnal Kesehatan Masyarakat, Vol.5,No.3, Juli 2017, pp.39-49

[21] Peraturan Menteri Ketenagakerjaan No.2 Tahun 2015 tentang Perlindungan Pekerja Rumah Tangga, in Press

[22] H.Idris, L.Trisnantoro, E.Satriawan, "Perluasan Kepesertaan Jaminan Kesehatan bagi Pekerja Sektor Informal (Studi Evaluasi Pra dan Pasca Jaminan Kesehatan Nasional)", Jurnal Kebijakan Kesehatan Indonesia, Vol.4, No.4, Desember 2015, pp. 138-145 